\title{
IMPLEMENTASI MODEL PEMBELAJARAN TEAM GAME TOURNAMENT UNTUK MENINGKATKAN HASIL BELAJAR BAHASA INGGRIS
}

\author{
Mohammad Umar
}

Madrasah Aliyah Negeri 1 Kudus

abineisam@gmail.com

DOI : http://doi.org/10.37730/edutrained.v5i2.154

Diterima: 23 November 2021 | Disetujui: 19 Desember 2021 | Dipublikasikan: 20 Desember 2021

\begin{abstract}
Abstrak
Permasalahan penelitian adalah apakah model pembelajaran Team Game Tournament (TGT) dapat meningkatkan hasil belajar Bahasa Inggris siswa kelas XI IPS-3 semester gasal MAN 1 Kudus Tahun Pelajaran 2018/2019. Tujuan penelitian ini untuk mengetahui penerapan model pembelajaran Team Games Tournament dalam meningkatkan hasil belajar Bahasa Inggris siswa kelas XI IPS 3 MAN 1 Kudus pada semester gasal tahun pelajaran 2018/2019. Hasil penelitian ini menunjukkan bahwa terdapat peningkatan hasil belajar Bahasa Inggris siswa kelas XI IPS-3, yang ditunjukkan dengan: (1) rata-rata hasil belajar pada siklus I 7,14; siklus II 7,44; dan 8,84 pada siklus III; (2) ketuntasan belajar pada siklus I adalah sebesar $47,22 \%$ dari seluruh siswa dan yang tidak tuntas $52,78 \%$; pada siklus II siswa yang telah tuntas $72,22 \%$ dan tidak tuntas $27,78 \%$; sedangkan pada siklus III, siswa telah tuntas 100\%; (3) ketuntasan belajar klasikal siklus I adalah 47,22\%, siklus II mencapai 72,22; dan siklus III mencapai $100 \%$.
\end{abstract}

Kata kunci: Team Game Tournament, model pembelajaran, hasil belajar.

\begin{abstract}
The problem of this research is whether the Team Game Tournament Learning Model (TGT) can improve the English learning achievement of calss XI IPS-3 students of MAN 1 Kudus in the even semester of the academic year 2018/2019. The purpose of this study is to find out that the implementation of the Team Game Tournament Learning Model (TGT) can improve English learning achievement of class XI IPS-3 students of MAN 1 Kudus in the even semester of the academic year 2018/2019. The results of the study showed that there is an improvement of the English learning achievement of class XI IPS-3 students. The improvement was indicated by: (1) the average learning achievement in cycle I is 7.14; cycle II 7.44; and 8.84 in cycle III; (2) the learning completion in cycle I is $47.22 \%$ of all students and the incompleted students is 52.78\%; the completed students in cycle II is $72.22 \%$ and the incompleted students is 27.78\%; in cycle III, the completed students in cycle III is 100\%; (3) the classical learning completion in cycle I is $47.22 \%$, in cycle II reaches 72.22 ; cycle III reaches $100 \%$.
\end{abstract}

Keywords: Team Game Tournament, learning model, learning achievement 


\section{PENDAHULUAN}

Tujuan mata pelajaran Bahasa Inggris dalam Kurikulum 2013 di Sekolah Menengah Atas dan/atau yang sederajat adalah untuk mengembangkan potensi peserta didik agar memiliki kompetensi komunikatif dalam wacana interpersonal, transaksional, dan fungsional, dengan menggunakan berbagai teks berbahasa Inggris lisan dan tulis, secara runtut dengan menggunakan unsur kebahasaan yang akurat dan berterima, tentang berbagai pengetahuan faktual dan prosedural, serta menanamkan nilai-nilai luhur karakter bangsa, dalam konteks kehidupan di lingkungan rumah, sekolah, dan masyarakat (Kemendikbud, 2014).

Sudah menjadi kewajiban semua Guru Bahasa Inggris untuk mewujudkan tujuan tersebut, namun sampai saat ini hal tersebut belum sepenuhnya terwujud. Kenyataan yang ada, masih ada siswa yang menganggap bahwa mata pelajaran Bahasa Inggris adalah momok. Setiap kali siswa ditanya mengenai apa kesulitan dalam belajar Bahasa Inggris, mereka menjawab memang pelajaran ini sulit.

Sebagai gambaran, hasil belajar siswa kelas XI IPS 3 MAN 1 Kudus pada ulangan harian yang rata-rata masih dibawah Kriteria Ketuntasan Minimal (KKM) yang ditetapkan, yakni 70. Ratarata hasil prestasi mereka adalah 55 . Selain itu, rata-rata nilai ulangan tengah semester gasal mapel Bahasa Inggris tahun pelajaran 2018/2019 yakni 50 . Jelas hasil ini masih jauh di bawah KKM. Penulis sebagai guru di kelas tersebut, tentu merefleksi diri ada permasalahan apa di kelas tersebut.

Data hasil penilaian formatif maupun penilaian tengah semester siswa kelas XI IPS 3 di atas jelas menunjukkan ada permasalahan di kelas tersebut. Permasalahan ini terkait motivasi berprestasi siswa. Selain itu siswa merasa jenuh dengan model pembelajaran yang diterapkan guru yang hanya ceramah dan tidak melibatkan siswa aktif dalam kelas.
Siswa cenderung acuh tak acuh saat belajar Bahasa Inggris. Bahkan diantaranya menyatakan bahwa pelajaran Bahasa Inggris tidak penting. Karena tidak menjadi bahan pertanyaan di kubur. Hal ini berakibat hasil prestasi siswa dalam pembelajaran Bahasa Inggris masih rendah.

Untuk itu perlu adanya penerapan model pembelajaran yang banyak melibatkan peran aktif siswa agar semangat belajar mereka meningkat. Guru seharusnya berusaha membuat pembelajaran yang menjadikan siswa mengalami sendiri dan motivasi mereka selalu meningkat.

Banyak pendekatan dan model pembelajaran yang dapat mengajak siswa aktif dalam pembelajaran. Salah satu model pembelajaran yang dapat digunakan adalah cooperative learning. Model pembelajaran ini dipandang sesuai untuk diterapkan di abad XXI, karena di dalamnya siswa dapat bekerjasama untuk memecahkan masalah (Problem Solver). Terdapat berbagai jenis/tipe model pembelajaran dalam pendekatan kooperatif ini, antara lain: Jigsaw, Group Investigation, Time Games Tournament (TGT), serta beberapa tipe yang lain.

Model pembelajaran Kooperatif tipe

Time Games Tournament (TGT) merupakan salah model pembelajaran yang dapat diterapkan guru dalam pembelajaran Bahasa Inggris. Berdasarkan penelitian yang telah dilakukan Ni Made Merti (Merti, 2020) tentang Penerapan Model Pembelajaran Teams Games Tournament (TGT) diketahui bahwa penerapan model pembelajaran Teams Games Tournament (TGT) dengan media audio visual dapat meningkatkan hasil belajar Bahasa Inggris siswa. Dari sinilah penulis tertarik dan ingin membuktikan sendiri jika model TGT dapat meningkatkan hasil belajar Bahasa Inggris siswa kelas XI IPS 3 MAN 1 Kudus pada semester gasal tahun pelajaran 2018/2019. 
Secara garis besar, implementasi TGT dalam pembelajaran merupakan pengembangan dari kegiatan Student Team Achievement Divisions (STAD) yang ditambah dengan permainan. Dalam hal ini, untuk menambah skor perolehan tim atau kelompok, dapat diberikan lagi oleh guru melalui permainan. Dengan demikian guru harus mempersiapkan satu permainan untuk dimainkan siswa setelah memberikan kuis (Slavin, 2005:24).

Ciri khas dalam pembelajaran kooperatif tipe TGT dengan pembelajaran koperatif lainnya adalah adanya turnamen. Dengan adanya turnamen diharapkan dapat menanamkan sportivitas siswa dan dapat meningkatkan motivasi siswa untuk berusaha lebih baik lagi bagi dirinya maupun untuk orang lain. Melalui turnamen diharapkan juga dapat membantu siswa menjadi lebih berani dalam berkompetisi. Sehingga siswa selalu berusaha untuk berada dalam posisi unggul karena mempunyai daya saing tinggi. Dengan demikian, tujuan penerapan model pembelajaran Team Game Tournament adalah peningkatan keaktifan siswa dalam pembelajaran dan juga adanya peningkatan hasil belajar siswa.

Permasalahan yang diangkat dalam penelitian ini adalah apakah penerapan model pembelajaran Team Games Tournament dapat meningkatkan hasil belajar bahasa Inggris siswa kelas XI IPS 3 MAN 1 Kudus pada semester gasal tahun pelajaran 2018/2019. Sedangkan tujuan dalam penelitian ini untuk mengetahui penerapan model pembelajaran Team Games Tournament dalam meningkatkan hasil belajar Bahasa Inggris siswa kelas XI IPS 3 MAN 1 Kudus pada semester gasal tahun pelajaran 2018/2019.

Hasil penelitian ini diharapkan dapat bermanfaat bagi guru, siswa, maupun praktisi pendidikan lainnya. Bagi guru, dapat menerapkan model pembelajaran kooperatif Team Games Tournament (TGT) untuk melibatkan siswa aktif dalam pembelajaran. Melalui penerapan model ini diharapkan dapat meningkatkan hasil belajar bahasa Inggris. Selain itu guru dapat menambah alternatif model pembelajaran yang dapat meningkatkan kemampuan siswa dalam memahami konsep dan menyelesaikan soal. Bagi siswa, penerapan model ini dapat menumbuhkan kemampuan siswa dalam memecahkan masalah yang berkaitan dengan pembelajaran. Selain itu, mereka dapat meningkatkan keaktifannya dalam pembelajaran dan menumbuhkan kebiasaan kerjasama dan komunikasi dengan teman dan kelompoknya, sehingga pada akhirnya diharapkan adanya peningkatan hasil belajar.

\section{KAJIAN PUSTAKA Model Pembelajaran Kooperatif}

Model pembelajaran kooperatif (cooperative learning) menurut (Rusman, 2015), merupakan pembelajaran yang dilakukan dengan cara membagi siswa ke dalam kelompok-kelompok kecil dengan anggota tidak lebih dari enam orang. Mereka belajar dan bekerjasama secara kolaboratif antar anggota yang heterogen.

Sedangkan menurut (Lestari, 2008) model pembelajaran kooperatif ini merupakan model yang sesuai dengan perkembangan abad ke-21 karena peserta didik dituntut berperilaku dan dapat bekerja serta belajar secara kolaboratif untuk mewujudkan keberhasilan bersama. Keberhasilan tersebut sangat dipengaruhi oleh keterlibatan dari setiap anggota kelompok itu sendiri, terutama dalam menyelesaikan tugas-tugas terstruktur. Selain itu alur proses belajar tidak harus berasal dari guru menuju peserta didik. Peserta didik bisa juga saling mengajar dengan sesama peserta didik lainnya. Model ini juga menekankan pada proses pencarian pengetahuan dari pada transfer pengetahuan. Peserta didik dipandang sebagai subyek belajar yang perlu dilibatkan secara aktif dalam proses pembelajaran.

Lebih lanjut dikatakan oleh (Lestari, 2008) bahwa dengan model pembelajaran kooperatif ini diharapkan dapat menjadi salah satu bentuk solusi permasalahan kualitas sumber daya 
manusia dalam jangka panjang. Apabila model ini berhasil direalisasikan, upaya ke arah penerapan paradigma baru pendidikan berbasis kompetensi dapat diwujudkan. Bagi bangsa Indonesia, penerapan model pembelajaran yang dapat memberikan fondasi bagi pembentukkan sumber daya manusia berkualitas memiliki nilai strategis untuk pembangunan dan penyiapan human capital.

\section{Model Pembelajaran Kooperatif Tipe Team Games Tournament (TGT)}

Menurut (Sudimahayasa, 2015:3) Teams-Games-Tournament (TGT) pada mulanya dikembangkan oleh David DeVries dan Keith Edwards. Model ini merupakan model pembelajaran yang dikembangkan oleh Johns Hopkins. Dalam model ini, para siswa dibagi dalam tim belajar yang terdiri dari empat sampai lima orang yang berbeda-beda tingkat kemampuan, jenis kelamin, dan latar belakang etniknya. Guru menyampaikan pelajaran, lalu siswa bekerja dalam tim mereka untuk memastikan bahwa semua anggota tim telah menguasai pelajaran. Selanjutnya diadakan turnamen, yaitu siswa memainkan game akademik dengan anggota tim lain untuk menyumbangkan poin bagi skor timnya. Pada model TGT terdapat dimensi kegembiraan dan kerjasama yang diperoleh dari penggunaan permainan. Teman satu tim akan saling membantu dalam mempersiapkan diri untuk permainan dengan mempelajari lembar kegiatan dan menjelaskan masalah-masalah satu sama lain, memastikan telah terjadi tanggung jawab individual.

Masih $\begin{gathered}\text { menurut } \\ \text { tahapan }\end{gathered}$
$\begin{gathered}\text { (Sudimahayasa, } \\ \text { pelaksanaan }\end{gathered}$
pembelajaran dengan model TGT dimulai dari tahap persiapan. Tahap ini meliputi; persiapan bahan ajar, penetapan siswa pada tim, serta penetapan siswa pada meja turnamen. Tahap selanjutnya adalah tahap pelaksanaan pembelajaran dengan langkah-langkah pembelajaran meliputi: (1) guru menyajikan materi seperti biasa, (2) guru membentuk kelompok belajar dan mengatur tempat duduk, (3) guru membagikan tugas kepada siswa, (4) guru mengajukan syarat siswa dapat mengerjakan tugas secara berpasangpasangan dua atau tiga orang kemudian mengecek pekerjaan di antara teman, (5) Guru memastikan bahwa setiap kelompok menunjuk satu orang siswa sebagai ketua kelompok. Ketua kelompok menetapkan bahwa setiap anggota telah memahami materi. Artinya jika ada pertanyaan, siswa dapat mengajukan pertanyaan ke satu teman dengan teman yang lain dalam satu kelompok sebelum mengajukan pertanyaan kepada siswa kelompok lain. (6) Guru bertindak sebagai narasumber atau fasilitator. (7) Guru memberikan kuis kepada siswa setelah selesai. Untuk menambah skor perolehan tim atau kelompok setelah melaksanakan tugas masing-masing diberikan suatu permainan. Tugas guru memberikan penghargaan kepada siswa yang dapat menjawab dengan benar dan kelompok yang mempunyai nilai tertinggi serta memberikan pengakuan atau pujian. Guru dapat memberikan tugas (PR) secara individu kepada setiap siswa. Terakhir dalam menutup kegiatan kelompok agar kembali ke tempat masing-masing. Kemudian guru memberikan tes formatif sesuai kompetensi yang diajarkan.

\section{Belajar dan Hasil Belajar}

Proses belajar mengajar menurut (Dasopang, 2017) sangat erat kaitannya dengan kegiatan pendidikan. Sebab dalam proses belajar mengajar terjadi interaksi antara guru dan siswa. Kegiatan belajar mengajar yang dilakukan untuk mencapai tujuan tertentu yang dirumuskan sebelum pembelajaran. Guru seharusnya sebelum mengajar perlu merencanakan kegiatan pendidikan secara sistematis.

Masih menurut (Dasopang, 2017), belajar didefinisikan sebagai proses perubahan perilaku peserta didik sebagai hasil dari interaksi siswa dengan lingkungannya. Perubahan perilaku terhadap hasil belajar bersifat terus menerus, fungsional, positif, aktif, dan 
terarah. Proses perubahan tingkah laku dapat terjadi dalam berbagai kondisi.

(Hamalik, 2004) mengungkapkan bahwa "pembelajaran adalah suatu kombinasi yang tersusun meliputi unsurunsur manusiawi, material, fasilitas dan prosedur yang saling mempengaruhi untuk mencapai tujuan."

Sedangkan menurut (Putri, 2017:2) belajar adalah proses yang kompleks, yang terjadi pada diri setiap orang sepanjang hidupnya. Interkasi antara seseorang dan lingkungannya menyebabkan proses belajar. Oleh karena itu belajar dapat terjadi kapan saja dan di mana saja. Salah satu pertanda bahwa seseorang belajar adalah adanya perubahan tingkah laku pada diri orang itu yang mungkin disebabkan oleh terjadinya perubahan pada tingkat pengetahuan, keterampilan atau sikapnya. Proses belajar mengajar pada dasarnya adalah penyampaian pesan dari sumber pesan kepada penerima pesan dengan cara atau media tertentu.

(Sutrisno, 2013) berpendapat bahwa tipe hasil belajar dibagi menjadi 3 (tiga), yaitu (1) Tipe hasil belajar kognitif, antara lain (a) Tipe hasil belajar pengetahuan (knowledge), (b) Tipe hasil belajar pemahaman (comprehensive), (c) Tipe hasil belajar penerapan (aplikasi), (d) Tipe hasil belajar analisis, (e) Tipe hasil belajar sintesis, (f) Tipe hasil belajar evaluasi. Bagian kedua dari tipe belajar adalah (2) tipe hasil belajar afektif ini berkaitan dengan sikap peserta didik. Ada beberapa tingkat bidang afektif dan tipe hasil belajarnya. Antara lain (a) receiving attending, yaitu kepekaan dalam menerima rangsangan dari luar, (b) responding, yaitu reaksi ang diberikan seseorang terhadap rangsangan dari luar, (c) valuing, yaitu penilaian (d) organizing, dan (e) karakteristik nilai internalisasi nilai, yakni keterpaduan dari semua system nilai yang dimiliki seseorang. Bagian terakhir dari tipe hasil belajar adalah (3) tipe hasil belajar psikomotorik, Ini berkaitan dengan (a) gerakan reflek (gerakan tidak sadar), (b) keterampilan pada gerakan sadar, (c) keterampilan perseptual, (d) kemampuan di bidang fisik, dan (e) gerakan gerakan skill dari keterampilan sederhana sampai yang kompleks, sedangkan (f) kemampuan berkomunikasi non decursive, seperti gerakan ekspresif dan interpretatif.

Dari berbagai tipe hasil belajar tersebut, pada penelitian ini penulis memprioritaskan tipe hasil belajar kognitif sebagai fokus permasalahan yang akan ditingkatkan, terutama hasil belajar Bahasa Inggris.

\section{METODE PENELITIAN}

Penelitian tindakan kelas ini dilaksanakan di kelas XI IPS 3 Madrasah Aliyah Negeri 1 Kudus yang terletak di Jalan Conge Ngembal Rejo Bae Kudus. Siswa di kelas XI IPS 3 berjumlah 36 siswa. Terdiri dari 26 siswa perempuan dan 10 siswa laki-laki.

Waktu dan tempat penelitian dalam waktu tiga bulan mulai bulan September sampai dengan bulan November pada semester gasal tahun pelajaran 2018/2019. Subjek penelitian ini adalah siswa kelas XI IPS 3 Madrasah Aliyah Negeri 1 Kudus Tahun Pelajaran 2018/2019.

Materi yang diajarkan dalam penelitian ini adalah materi "Opinion and Thought." Pelaksanaan penelitian dimulai dari kegiatan observasi dan pengumpulan data awal, perencanaan, pelaksanaan siklus I, pelaksanaan siklus 2, dan pelaksanaan siklus 3 serta penyusunan laporan. Adapun jadwal penelitian sebagai berikut:

Tabel 1: Jadwal Penelitian

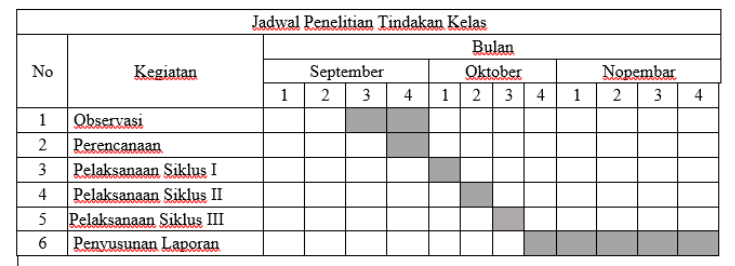

Siklus pada penelitian tindakan kelas ini dilaksanakan dalam beberapa tahap yaitu: perencanaan, pelaksanaan, pengamatan dan relfeksi. Bagan pelaksanaan siklus penelitian adalah sebagai berikut: 


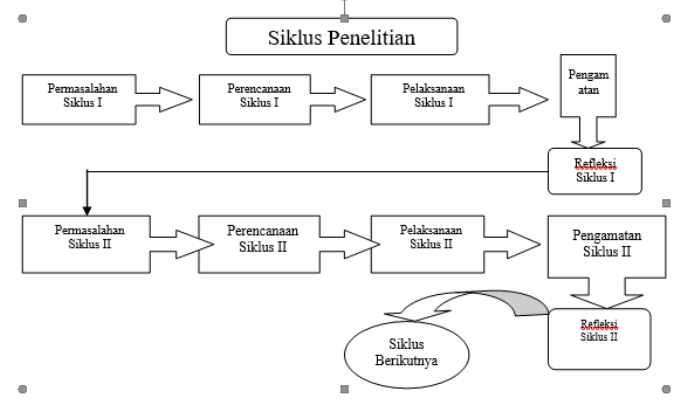

Gambar1: Siklus Penelitian Tindakan Kelas

Penjelasan singkat pada setiap siklus dapat penulis uraikan sebagai berikut. Pada tahap perencanaan meliputi: (1) pembuatan rencana pembelajaran dengan TGT, (2) penyusunan Lembar Kerja Siswa (LKS), (3) pembentukan kelompok siswa dengan memperhatikan keseimbangan kemampuan dalam kelompok, (4) menyusun lembar observasi siswa untuk mengamati aktivitas komunikasi siswa dan guru dalam penerapan model TGT.

Pada tahap pelaksanaan, meliputi langkah-langkah sebagai berikut: (1) penjelasan materi sesuai perencanaan dengan mengacu pada langkah-langkah penerapan TGT, (2) membagi siswa ke dalam beberapa kelompok, membagikan LKS dan soalnya. Pada tahap ini guru sekaligus melakukan pengamatan dan motivasi kepada siswa. (4) pelaksanaan diskusi dalam kelompok, (5) perwakilan kelompok mempresentasikan hasil diskusi, (6) presentasi siswa, dilanjutkan tanya jawab. Selanjutnya pada akhir pembelajaran dilaksanakan evaluasi.

Tahap pengamatan (observasi) meliputi pengamatan terhadap aktivitas siswa dan guru dalam pembelajaran dengan menerapkan model Team Game Tornament (TGT). Pada tahap refleksi, peneliti melakukan analisis terhadap hasil pengamatan serta data hasil belajar siswa. Kendala pada siklus 1 akan dijadikan permasalahan yang akan dilakukan tindakan perbaikannya pada siklus II, kemudian dilanjutkan dengan merancang perbaikan tindakan pada siklus III apabila siklus II dinyatakan belum berhasil.
Sumber data pada penelitian ini adalah guru dan siswa, dengan jenis data kualitatif dan kuantitatif. Data kualitatif berupa hasil pengamatan terhadap aktivitas guru dan siswa selama berlangsungnya pembelajaran yang dikumpulkan melalui lembar observasi guru dan siswa. Sedangkan data kuantitatif berupa berupa nilai yang diperoleh dari hasil pelaksanaan evaluasi hasil belajar siswa. Data hasil belajar siswa ini dianalisis dengan cara membandingkan nilai perolehan siswa dengan ketuntasan belajar minimal, baik secara individu maupun klasikal.

Pelaksanaan penelitian pada masingmasing siklus melalui penerapkan model Team Game Tournament (TGT) dinyatakan berhasil apabila hasil belajar siswa yang mampu mencapai KKM sekurang-kurangnya $80 \%$ dari seluruh siswa. Adapun KKM untuk mata pelajaran Bahasa Inggris adalah 75.

\section{HASIL PENELITIAN DAN PEMBAHASAN}

Tujuan penelitian tindakan kelas ini adalah untuk mengetahui penerapan model pembelajaran Team Games Tournament (TGT) dalam meningkatkan hasil belajar Bahasa Inggris siswa kelas XI IPS 3 MAN 1 Kudus. Untuk itu pembahasan hasil penelitian tindakan kelas ini didasarkan pada hasil pengamatan terhadap pelaksanaan pembelajaran pada seluruh siklus, mulai dari sikuls I, II, dan III, terutama fokus pada hasil belajar siswa, baik hasil belajar individu maupun klasikal.

Setelah pembelajaran dengan model Team Games Tournament (TGT) pada siklus I, siklus II, dan siklus III selesai dilaksanakan, dapat dikemukakan data hasil belajar siswa sebagai berikut: 
Tabel 2: Hasil Siklus I, II, dan III

\begin{tabular}{|l|l|c|c|c|c|c|c|}
\hline \multirow{2}{*}{ No } & \multirow{2}{*}{ Hasil Evaluasi } & \multicolumn{2}{|c|}{ Sikkus I } & \multicolumn{2}{c|}{ Siklus II } & \multicolumn{2}{c|}{ Sikkus III } \\
\cline { 3 - 8 } & Skor & $\%$ & Skor & $\%$ & Skor & $\%$ \\
\hline 1 & Rata-rata & 7,14 & 71,44 & 7,44 & $74,44 \%$ & 8,84 & $88,44 \%$ \\
\hline 2 & Nilai tertinggi & 8,00 & & 8,40 & & 10,00 & \\
\hline 3 & Nilai terendan & 5,60 & & 5,60 & & 8,00 & \\
\hline 4 & $\begin{array}{l}\text { lumlah siswa } \\
\text { yang tuntas }\end{array}$ & 17 & $47,22 \%$ & 26 & $72,22 \%$ & 36 & $100 \%$ \\
\hline 5 & $\begin{array}{l}\text { lumlah siswa } \\
\text { tidak tuntas }\end{array}$ & 19 & $52,78 \%$ & 10 & $27,78 \%$ & 0 & $0 \%$ \\
\hline 6 & $\begin{array}{l}\text { Ketuntassan } \\
\text { klasikal }\end{array}$ & $47,22 \%$ & & $72,22 \%$ & & $100 \%$ \\
\hline
\end{tabular}

Dari tabel tersebut dapat diketahui bahwa rata-rata hasil belajar siswa pada siklus I adalah 7,14, dengan nilai tertinggi 8,00 dan nilai terendah 5,60. Siswa yang memenuhi kriteria tuntas belajar sebanyak 17 siswa atau $47,22 \%$ dan yang tidak tuntas sebanyak 19 siswa atau $52,78 \%$. Sedangkan ketuntasan hasil belajar siswa klasikal baru mencapai 47,22\%.

Pada siklus II diketahui bahwa terjadi peningkatan hasil belajar siswa, yaitu mencapai rata-rata 7,44 , dimana nilai tertinggi 8,40 dan nilai terendah 5,60. Siswa yang memenuhi kriteria tuntas belajar sebanyak 26 siswa atau 72,22\% dan tidak tuntas 12 siswa atau 27,78\%. Sementara ketuntasan hasil belajar klasikal meningkat menjadi 72,22\%.

Pada siklus III, diperoleh nilai ratarata 8,84, dengan nilai tertinggi 10,00 dan nilai terendah 8,00. Ini menunjukkan bahwa hasil belajar siswa pada siklus III mengalami peningkatan dibandingkan dengan siklus II. Pada siklus III ini, siswa yang tuntas sebanyak 36 siswa atau $100 \%$, dan tidak ada siswa yang tidak tuntas belajar. Sedangkan ketuntasan hasil belajar siswa secara klasikal sudah mencapai 100\%. Hasil ini sudah memenuhi kriteria keberhasilan penelitian yang telah ditetapkan, yaitu ketuntasan belajar klasikal sekurangkurangnya harus mencapai prosentase $80 \%$.

Dari paparan pembahasan di atas, dapat diketahui bahwa permasalahan yang diangkat dalam penelitian tindakan kelas ini, yaitu apakah terdapat peningkatan hasil belajar Bahasa Inggris siswa kelas XI IPS 3 Madrasah Aliyah Negeri 1 Kudus pada semester gasal tahun pelajaran 2018/2019 setelah diterapkan model pembelajaran TGT, sudah terjawab. Terbukti hasil belajar siswa kelas XI IPS 3 pada setiap siklus selalu mengalami peningkatan. Hal ini menunjukkan bahwa penerapan model pembelajaran Team Game Tournament (TGT) dapat meningkatkan hasil belajar pembelajaran Bahasa Inggris.

\section{PENUTUP}

\section{Simpulan}

Berdasarkan analisis data hasil penelitian dan pembahasan, diperoleh kesimpulan bahwa penerapan model pembelajaran Team Game Tournament (TGT) yang telah dilaksanakan pada siswa kelas XI IPS 3 MAN 1 Kudus pada semester gasal tahun 2018/2019 terbukti dapat meningkatkan hasil belajar Bahasa Inggris. Hal ini ditunjukkan adanya peningkatan hasil belajar siswa pada setiap siklus. Peningkatan hasil belajar ini ditunjukkan dengan (1) rata-rata hasil belajar pada siklus I ssebesar 7,14; siklus II sebesar 7.44; dan rata-rata siklus III sebesar 8,84; (2) Siswa yang memenuhi kriteria tuntas belajar pada siklus I sebesar 47,22\% dan tidak tuntas sebesar $52,78 \%$; pada siklus II siswa yang memenuhi kriteria tuntas sebesar $72,22 \%$ dan tidak tuntas 27,78\%; sedangkan pada siklus III seluruh siswa telah memenuhi kriteria tuntas $(100 \%)$; (3) ketuntasan hasil belajar siswa secara klasikal pada siklus I sebesar 47,22\%, pada siklus II mencapai 72,22; dan pada siklus III sebesar 100\%.

\section{Saran}

Dalam melaksanakan proses pembelajaran setiap guru perlu melakukan variasi pendekatan, strategi, maupun model pembelajaran yang sesuai dengan materi yang akan disampaikan serta karakteristik siswa. Salah satu model pembelajaran yang dapat digunakan oleh guru yaitu Team Game Tournament (TGT) karena telah terbukti dapat meningkatkan hasil belajar siswa . 



\section{DAFTAR PUSTAKA}

Dasopang, A. P. (2017). Belajar Dan Pembelajaran. Fitrah Jurnal Kajian IImu-IImu Keislaman Vol. 03 No. 2 Desember 2017 e-ISSN : 2460-2345, p-ISSN: 2442-6997, 333-334.

De Porter, B., \& Mike, H. (1992). Quantum Learning. Membiasakan Belajar Nyaman dan Menyenangkan. (A. Abdurrahman, Penerj.) Bandung: Perbit Kaifa.

Fathurrohman, M. R. (2018). Perbandingan Model Pembelajaran Kooperatif Learning Teknik Jigsaw Dengan Teknik Stad Pada Kelas X Di MA Miftahunnajah. Bandung: Program Studi Biologi Fkip Universitas Pasundan Bandung.

Hamalik, Oemar. (2004). Proses Belajar Mengajar. Bandung: Bumi Aksara.

Horshit. (2014). Evaluation of Training and Development: An Analysis of Various Model. Journal of Bussiness and Management, 5(2), 16-17. doi:https://doi.org/10.9790/487X-0521622

Kemendikbud. (2014). Kurikulum 2013 Pedoman Guru Mata Pelajaran Bahasa Inggris Untuk SMA/MA, SMA/MAK. Jakarta: Pusat Kurikulum Dan Perbukuan Balitbang Kemendikbud.

Latifah, F. A., Samsudi, \& Masrukan. (2014). Model Supervisi Akademik Kelompok Berbasis Think Talk Write Untuk Peningkatan Kemampuan Guru Menyusun Karya Tulis IImiah. Educational Management, 3(1). Diambil kembali dari https://journal.unnes.ac.id/sju/index.php/eduman/article/view/4357

Lestari, B. ( 2008). Peningkatan Kualitas Pembelajaran Dengan Model Pembelajaran Cooperative Learning. Jurnal Ekonomi \& Pendidikan, Volume 5 Nomor 2, Desember, 146.

Merti, N. M. (2020). Penerapan Model Pembelajaran Teams Games Tournament (TGT) . Journal of Education Action Research, 315.

Pusdiklat Tenaga Teknis Pendidikan dan Keagamaan. (2018). Dokumen II Kurikulum Diklat Teknis Substantif Pendidikan. Jakarta: Pusdiklat Tenaga Teknis Pendidikan dan Keagamaan.

Rusman. (2015). Pembelajaran Tematik Terpadu, Teori dan Praktik. Jakarta: Gravindo.

Slavin, Robert E. (2005). Cooperative Laerning. London: Allymand Bacon.

Sugiyono. (2007). Statistika untuk Penelitian. Bandung: CV Alfabeta.

Suparno. (2000). Langkah-langkah Penulisan Artikel IImiah. Dalam A. Saukah, \& M. Waseno, Menulis Artikel untuk Jurnal Ilmiah. Malang: UM Press.

Sutrisno, B. (2013). Peningkatan Hasil Belajar Siswa Dalam Pembelajaran Matematika Dengan Menggunakan Teropong Pecahan Di Kelas V Sekolah Dasar. Program Studi Pendidikan Guru Sekolah Dasar Fkip Untan, 2.

Tea, T. (2009). Inspiring Teaching: Mendidik Penuh Inspirasi. Jakarta: Gema Insani. 